\title{
Dylematy terapeutycznej wielokulturowości. Pomiędzy swojskością a innością
}

\section{KEY WORDS}

multiculturalism, identity, difference, therapist, therapeutic process

\begin{abstract}
Teusz Grażyna, Dylematy terapeutycznej wielokulturowości. Pomiędzy swojskością a innością [The Dilemmas of Therapeutic Multiculturalism. Between Familiarity and Otherness]. Kultura - Społeczeństwo Edukacja nr 2(10) 2016, Poznań 2016, pp. 181-189, Adam Mickiewicz University Press. ISSN 2300-0422. DOI 10.14746/kse.2016.10.14.

The article is an attempt to analyze the phenomenon of multiculturalism and the issues to accompany in the context of building and achieving human identity. The main emphasis is placed on presenting the psychosocial dimension of constructing identity and its interactive character. Social identity is the other essential part of the issue next to individual identity. The objects of the author's attention here are therapeutic implications and dilemmas presented in the context of multiculturalism.
\end{abstract}

Wielokulturowość, jako zjawisko cywilizacyjne, niesie ze sobą wielorakie konsekwencje, które dotykają różnorakich sfer społecznego i jednostkowego funkcjonowania w świecie i modelują sposób odniesienia do rzeczywistości. Kształtują się w jej wyniku nowe modele, nowe wzorce i paradygmaty współistnienia tego, co uniwersalne i partykularne, co ogólne i szczegółowe. Rodzi się w tej sytuacji pytanie: jak pogodzić uniwersalizm z partykularyzmem, ogólność ze szczegółowością? Nade wszystko zaś kwestią zasadniczą staje się refleksja nad wspólnotową i jednostkową tożsamością, nad kategoriami „podobieństwa” i „różnicy”, „swojskości” i „inności”, „jedności” i „odmienności”.

\section{Założenia teoretyczne}

Na początek dwie ważne konstatacje, które w artykule Wielokulturowość: za i przeciw. (Kilka uwag) formułuje Andrzej Szahaj. Pierwsza: istnieją dwie odmienne, aczkolwiek nie osobne i odseparowane od siebie rzeczy: ideologia wielokulturowości i prak- 
tyka wielokulturowości. Druga: wielokulturowość odnosi się przede wszystkim do ludzkiej świadomości, a dopiero w dalszej kolejności do ludzkich zachowań (Szahaj, 2010: 25-26) ${ }^{1}$. Rozwijając swoje tezy, autor stwierdza:

Praktyka społeczna wielokulturowości ukazuje możliwość bycia człowiekiem na inny sposób niż nasz, co może skłonić do krytycznej refleksji nad sobą, a następnie do ewentualnej zmiany lub potwierdzenia tego, co znane, przeprowadzonych jednak w każdym przypadku po krytycznym sprawdzeniu jego wartości. Wyrywa ona z zadowolenia wynikającego często z braku uświadomienia sobie alternatywy dla przyjętego sposobu egzystencji, zmusza do namysłu nad naszym życiem. (Szahaj, 2010: 27)

Następnie zaś zauważa, że to stan świadomości ludzi wyznacza kulturową matrycę identyfikacji i przynależności do „swoich” na poziomie wspólnoty przekonań, co modeluje w swoisty sposób aksjologię odrębności. „Do pewnego stopnia to świadomość różnicy wytwarza zatem różnicę" (Szahaj, 2010: 26). Na poziomie świadomości i praktyki wielokulturowości ma miejsce, kontynuuje Szahaj, swoiste rozszerzenie kulturowej i aksjologicznej wyobraźni. Pisze:

Rozszerzenie owo dokonuje się poprzez pokazanie, że istnieją inne sposoby życia, na swój sposób wartościowe, które mogą uświadomić nam ograniczoność lub płytkość naszego własnego sposobu życia, jego jednowymiarowość bądź zawarty w nim brak wrażliwości na pewne aspekty świata czy życia. (...) Pozwala nam uczyć się od innych i poprzez krytyczną konfrontację podawać w wątpliwość to, co było tak nam na tyle bliskie, że nie byliśmy w stanie zobaczyć jego niekonieczności, ujawniać nasze przesądzenia kulturowe, a w ten sposób zdobywać wiedzę o tym, kim jesteśmy i co faktyczni myślimy i czujemy. (Szahaj, 2010: 27)

W konsekwencji, jak zaznacza autor, poszerzona wyobraźnia kulturowa, prowadząc do wzrostu samorefleksji i samokrytycyzmu, przyczynia się bardzo często do wzrostu kreatywności społecznej i podniesienia jakości życia (Szahaj, 2010: 27-28). Można by powiedzieć, że swoistym miernikiem tych nowych możliwości, sui generis barometrem rejestrującym zachodzące w tym zakresie zmiany, byłaby otwierająca się perspektywa indywidulanych wyborów i decyzji, zróżnicowane spektrum potencjalnych wariantów osobowej samorealizacji. Horyzont wyłaniających się konstelacji znaczeń i wartości przekładałby się też na ewolucję procesu osiągania i konstytuowanie się jednostkowej autonomii.

\section{Kwestia tożsamości}

Zbudowanie i osiągnięcie tożsamości jest jednym z najważniejszych zadań stojących przed człowiekiem. Wyłaniają się tutaj dwa zasadnicze pytania, które stawia

\footnotetext{
${ }^{1}$ Do zagadnienia ideologii wielokulturowości odsyła autor do swojej książki E pluribus unum? Dylematy wielokulturowości i politycznej poprawności. Kraków 2004.
} 
sobie jednostka i próbuje znaleźć na nie odpowiedź: „Kim jestem?” i „Kim mógłbym być?". Tożsamość jest zadaniem, z którym musi się ona zmierzyć, jest pewnym projektem do realizacji, procesem, ma charakter potencjalnie otwarty i temporalny - konstruuje się w czasie. Tożsamość to pewien "horyzont aksjologiczny” człowieka, punkt orientacyjny dla tego, co dla niego najważniejsze i co wyznacza jego miejsce $\mathrm{w}$ świecie. Ma ona charakter indywidualny i musi być wybrana, nie zaś narzucona i arbitralnie ustanowiona. W poczuciu tożsamości dochodzi do głosu doświadczenie niepowtarzalności oraz indywidualności własnego osobowego istnienia, ten szczególny rodzaj bycia sobą jako kimś jedynym i odrębnym. „Być sobą, jak wyjaśnia Emmanuel Lévinas, to - niezależnie od wszelkiej indywiduacji, którą się uzyskuje na bazie jakiegoś systemu odniesienia - posiadać tożsamość jako treść wewnętrzną" (Skarga, 1997: 136). „Tożsamość osobowa jest więc kwestią samoświadomości" zauważa z kolei Charles Taylor (zob. Taylor, 2001: 98). Próbując określić genezę tożsamości nowoczesnej oraz opisać historię poglądów dotyczącą tego, „co to znaczy być istotą ludzką," jest zdania, że „istnieje bliski związek pomiędzy różnymi (...) warunkami tożsamości, czyli warunkami tego, by czyjeś życie miało sens" (Taylor, 2001: 104). Manuel Castells zaś stwierdza, że "tożsamość staje się głównym, a czasem jedynym źródłem sensu” (Castells, 2007: 21).

Istnieje zatem społeczny czy może bardziej psychospołeczny wymiar konstruowania tożsamości, którego zasadniczym wyrazem jest jej relacyjny, a właściwie interakcyjny charakter. Tożsamość kształtuje się w procesie dialogu, negocjacji, sporu, agonu, jest rezultatem tworzenia siebie $\mathrm{w}$ wyniku spotkania, interakcyjnej „rozmowy” $\mathrm{z}$ innymi, ze społecznym i kulturowym otoczeniem (Trzópek, 2008: 133-160). W tej optyce ujawnia się również uświadomienie sobie i faktyczne doświadczenie różnicy, której poznawcze i emocjonalne „opracowanie” jest jednym z warunków wytworzenia, uzyskania tożsamości. Owa oscylacja przebiega według schematu: przynależność - odrębność (Sikora, 2008: 37-38). Istotnym wymiarem osiągania tożsamości jest też poczucie względnej spójności i ciągłości własnego ja, własnej historii życia (Sokolik, 1993: 10). Ugruntowane przeświadczenie jednostki, że mimo zmieniających się warunków otoczenia pozostaje ona tą samą osobą i, co nie mniej ważne, że zmiany zachodzące w jej życiu tworzą pewną sensowną całość, pozostaje zasadniczą koniecznością wpływającą na postać jej egzystencjalnego poczucia identyfikacji bytowej, scalającą fragmentaryczne jakości i doznania, tak w wymiarze cech osobowości, jak i kontekstualnych wyznaczników istnienia, sytuacji i okoliczności w których funkcjonuje - czasu, miejsca i roli społecznej. Inaczej mówiąc, dokonuje się podwójna integracja osobowości - synchroniczna i diachroniczna (Cieciuch, 2011: 115). Ta pierwsza polega „na powiązaniu różnych zachowań, cech, wydarzeń, współwystępujących w danym przedziale czasowym” (Cieciuch, 2011: 115), ta druga 
z kolei „wyjaśnia przebieg dotychczasowego życia, które konstytuuje obecny jego kształt" (Cieciuch, 2011: 116). W ten sposób tworzy się, oparta na autobiograficznych faktach, indywidualna historia życia, która zarazem owe fakty transcenduje, „stanowiąc rekonstrukcję przeszłości, percepcję teraźniejszości i antycypację przyszłości” (Cieciuch, 2011: 116).

Sytuacja wielokulturowości oraz implikowane przez nią własności i sposoby życia $\mathrm{w}$ spotkaniu $\mathrm{z}$ zagadnieniem tożsamości generuje dodatkowe spektrum kwestii i problemów do rozważenia, ponieważ obok tożsamości jednostkowej pojawia się kwestia „tożsamości społecznej” (Niedźwiecki, 2010: 133), wyrażająca się w swoiście doświadczanym procesie przynależności oraz identyfikacji zbiorowej, kolektywnej i sposobu odnoszenia się do niego konkretnych jednostek (Niedźwiecki, 2010: 135). Poczucie własnej tożsamości kształtuje się jakby w nowej konstelacji znaczeń i wektorów sił, w odpowiedzi nie tylko na pytania o to, „kim jestem?' i „kim mógłbym być?”, ale w sposób szczególny uwypukla i uwyraźnia pytanie o własną, biograficzną historię - „skąd jestem?”

\section{Wielokulturowość a tożsamość}

W aspekcie zatem wielokulturowości jako zjawiska i procesu tożsamość jawi się jako zadanie, które jednostka ma podjąć i zrealizować poprzez swoją biografię w określonych, bardzo szczególnych warunkach społeczno-kulturowych. Wielokulturowość bowiem wyłania specyficzne elementy scalające (integrujące) i dekomponujące (dezintegrujące, fragmentujące) jednostkową tożsamość. Jak zauważa Arthur Schlesinger: „Im bardziej ludzie czują, że dryfują w pustym, bezosobowym, anonimowym morzu, tym bardziej rozpaczliwie zmierzają ku znajomemu, zrozumiałemu schronieniu, tym bardziej hołdują politykę tożsamości. Integracja i dezintegracja żywią się sobą nawzajem” (Szahaj, 2004: 131). Tożsamość, która stać się ma zasadniczym elementem stabilizującym jednostkowe istnienie na poziomie jego sensu, konstytuuje się niejako symultanicznie, w równoczesnym procesie świadomościowego konstruowania jednostkowej i wspólnotowej identyfikacji. Wielokulturowość modeluje szczególny styl życia jednostki, w którym procesy rekonstrukcji, redefinicji, reinterpretacji stanowią ważny element weryfikujący spójność i ciągłość oraz poczucie odrębności, co stanowi istotny wyznacznik tożsamości. Zdefiniowanie swojej odrębności dokonuje się niejako na przecięciu dwóch wektorów: statycznego współistnienia i dynamicznego przenikania.

Wydaje się, że w kontekście wielokulturowości tożsamość dobrze wyrażają dwa modelowe jej ujęcia: interakcyjne i światopoglądowe (Szahaj, 2004: 131). Model interakcyjny akcentuje trzy kwestie objaśniające procesy samoidentyfikacji i identyfikowania innych: 
Po pierwsze, tożsamość jest zjawiskiem interakcyjnym, ponieważ autoidentyfikacja i definiowanie innych przebiega za pośrednictwem zasobów symbolicznych, dostępnych w ramach danej kultury, przede wszystkim języka. One decydują o możliwości poprawnego interpretowania sygnałów dotyczących postrzegania nas przez innych, czyli kształtowania jaźni odzwierciedlonej, a także formowania naszych komunikatów dotyczących interpretowania rzeczywistości, które zrozumiałe są dla partnerów interakcyjnych. Po drugie, uzyskiwanie tożsamości następuje $\mathrm{w}$ trakcie interakcji, wysyłania, przyjmowania i interpretowania przekazów. Bez niej zarówno identyfikacja wewnętrzna, jak i zewnętrzna podmiotu byłaby niemożliwa. Po trzecie, tożsamość jest realizowana, przejawia się w ludzkich działaniach. To one są odzwierciedleniem samoidentyfikacji i identyfikowania innych w codziennym życiu. (Szahaj, 2004: 136)

Konstruowanie tożsamości obok czasu interakcyjnego - oddziaływania jednostek na siebie - zawiera też czas wewnętrzny, świadomościowy, czas biograficzny, odnoszący się do doświadczenia życiowego, oraz czynniki sytuacyjne. Tożsamość społeczna dokonuje się zatem $\mathrm{w}$ koniunkcji czasu interakcyjnego i historycznego (Szahaj, 2004: 136). Jej konstytutywnym elementem są także wynikające $\mathrm{z}$ modelu światopoglądowego style życia, wzory, normy postępowania (Szahaj, 2004: 137).

Proces konstruowania jednostkowej tożsamości jest ściśle skorelowany z kulturowymi wzorcami, które wypełniają style życia, generując tym samym tożsamościowe projekty „ja”. Styl życia, jak to ujmuje Anthony Giddens, to

mniej lub bardziej zintegrowany zespół praktyk, które podejmuje jednostka, nie tylko dlatego, że są użyteczne, ale także dlatego, że nadają materialny kształt poszczególnym narracjom tożsamościowym. (...) Ze stylem życia wiąże się zespół nawyków i orientacji, dzięki którym tworzy on pewną, ważną dla poczucia ontologicznego, całość, w obrębie której różne opcje tworzą mniej lub bardziej uporządkowany wzór. (Giddens, 2001: 113-114)

„Wielokulturowy sposób istnienia” w kształtowania się refleksyjnego projektu „ja”, według Giddensa, generuje następujące dylematy tożsamościowe, które są wynikiem wpływu wielokulturowych procesów na lokalny kontekst egzystencji i działania:

- unifikacja - fragmentaryzacja: nieustanne krzyżowanie się tendencji integrujących, unifikujących, ujednolicających z procesami fragmentacji, oddzielenia, rozproszenia;

- bezsilność - kontrola: oscylowanie między koniecznością wyboru, która staje się źródłem bezsilności, a poczuciem kontroli nad zróżnicowanymi możliwościami kształtowania swojego „ja”;

- autorytet - niepewność: rozdarcie pomiędzy pewnością istnienia autorytetów, instancji odwoławczych, a odczuciem ich utraty i doświadczeniem pustki (Giddens, 2001: 269-270). 
Wokół tych dylematów dokonuje się, zdaniem badacza, poszukiwanie podstaw spójności budowanej tożsamości w czasach wyznaczonych przez wielokulturowość. W ramach zaprojektowanej przez nią scenerii odbywa się konstruowanie indywidualnego projektu tożsamościowego oraz jego ewentualna przebudowa i przekomponowywanie. Wskazane dylematy stanowią sui generis ramę obiegu, cyrkulacji znaczeń wielokulturowych przepływów znaczeń i wartości.

W wyznaczonym przez nie kontekście pojawia się pytanie o własne kulturowe „zakorzenienie, zakotwiczenie, osadzenie” tożsamości jednostki. Tożsamość zatem uzyskiwana/wypracowywana w optyce wielokulturowości, pojmowanej jako sytuacja współbycia, współegzystowania jednostek reprezentujących odmienne kultury, reprezentujących odmienne systemy przekonań o charakterze ontologicznym, epistemologicznym, a nade wszystko aksjologicznym - światopoglądowym, obyczajowym, etycznym, estetycznym, to uświadomiona alternatywa rozwinięcia modyfikowanego ciągle projektu „ja”. Tożsamość w kontekście wielokulturowości rodzi się $\mathrm{w}$ procesie konieczności ciągłego balansowania pomiędzy pułapkami esencjalizmu, który Tariq Modood ujmuje jako przeświadczenie, że „każda kultura ma swoją unikalną, stałą zawartość (esencję)” (Budakowska, 2009: 152; zob. także: Galent, 2014: 61-68) i uniwersalizmu. Tożsamość zatem osiągana jest $\mathrm{w}$ przestrzeni wielokulturowości jako spektrum uświadamianych różnic, w przestrzeni ciągłej renegocjacji dokonującej się pomiędzy „swojskością" a „innością". Staje się próbą wypracowywania swoistego „paktu o nieagresji” między partykularyzmem a uniwersalizmem, w sytuacji wyłaniającej coraz to „inne mechanizmy scalające i rozmontowujące naszą tożsamość” (Budakowska, 2009: 155).

\section{Terapeutyczne implikacje i dylematy w kontekście wielokulturowości}

Najważniejsze instrumenty $\mathrm{w}$ pracy terapeutycznej to: sam terapeuta jako człowiek (wymiar ludzki), a także jako specjalista, profesjonalista, ekspert (wymiar zawodowy). „Terapeuta jednocześnie terapeutyczny” (Corey, 2005: 38), a więc przyglądający się swoim poglądom i analizujący je w określonym kontekście. Co to oznacza w sytuacji wielokulturowości, w uruchomionych przez nią procesach, tendencjach i trendach? W pierwszym rzędzie znajomość specyfiki oraz jakości własnej kultury, świadomość własnej tradycji oraz wyczulenie na własne dziedzictwo kulturowe. Jak twierdzi Gerald Corey, „skuteczny terapeuta biegły w kwestiach wielokulturowości (...) wie wszystko na temat swojego dziedzictwa rasowego i kulturowego i tego, jak ta spuścizna ukształtowała go osobiście i zawodowo” (Corey, 2005: 51). Reflektowanie kategorii „swojskości”, szczególnie 
przez pryzmat pozytywnych, jak i negatywnych reakcji emocjonalnych wobec „inności”, pozwala rozumieć specyfikę oraz znaczenie kręgów kulturowych w ogóle oraz ich wpływ na jednostkę - własnej kultury na siebie i odmiennej na klienta. Terapeuta $\mathrm{w}$ swojej terapeutycznej aktywności staje się tym samym osobą, która potrafi znaleźć właściwy balans w spotkaniu wartości własnej kultury i, niekiedy bardzo odmiennej czy nawet radykalnie innej, szczególnie gdy chodzi o kwestie światopoglądowe, kultury klienta. Wiedza o własnej kulturze i o kulturze innych determinuje skuteczność komunikacji. Jak czytamy w książce Mosty zamiast murów. Podręcznik komunikacji interpersonalnej:

Można zrozumieć zachowania innych jedynie wtedy, gdy rozpatruje się je w kontekście ich kultury, (...) w odniesieniu do tła kulturowego, z którego powstały. Żadna z cech kulturowych nie jest „dobra” ani „zła”; jedynie „różna” od cech innych kultur. (Stewart, 2000: 525-526)

Terapeuta szanuje wartość różnicy, różnorodności, odmienności kulturowych, rozumiejąc na przykład doniosłość i wagę kulturowych granic, na przykład tabu kulturowego. W szerszym aspekcie powinien być tym, kto uświadamia sobie reguły gry związane ze wspólistnieniem kultur na przełomie XX i XXI wieku, w epoce globalizacji, mobilność znaczeń i form metaforyczno-symbolicznych oraz potrafi dostrzec, jak bardzo $\mathrm{w}$ procesie globalizacji, kulturowe środowiska znaczeń stają się w coraz większym stopniu plastyczne i amorficzne, ruchome i negocjowalne. Stara się rozumieć fenomen sympatii i antypatii, to, jak on powstaje, i potrafić się z nim „obchodzić”. Umiejętnie uwzględniać, we właściwy sposób i we właściwych proporcjach, kwestie różnic natury etycznej z pespektywy wielokulturowości. Wystrzega się nadmiernej generalizacji, krańcowych i „sztywnych” rozpoznań i konstatacji wypracowanych na podstawie pojedynczego przypadku i nie stosować uogólnionych poglądów do, jawiących się z pozoru i na pierwszy ogląd, podobnych przypadków, wydarzeń lub kontekstów. Terapeuta powinien dystansować się wobec wszelkich form determinizmu poznawczego i traktować kultury jako autonomiczne, zindywidualizowane matryce znaczeń, które nie dają się wpisać w konwencjonalne wyobrażenia, zarazem jednak być też świadomy procesu „krzyżowania się” różnych środowisk znaczeń oraz niejednokrotnie ich „palimpsestowego" charakteru. Nie wyolbrzymia, nie hiperbolizuje, ale i nie umniejsza, nie minimalizuje czy deprecjonuje, nie dokonuje subiektywnej abstrakcji i wnioskowania. Cechować go powinna umiejętność mądrego, empatycznego balansowania pomiędzy intelektualnymi procesami kategoryzacji i partykularyzacji zjawisk, docenianie ich wagi w procesie myślenia i wartościowania. Powinien rozumieć wagę każdego z nich, ponieważ „jeden (...) służy zbieraniu, grupowaniu rzeczy, drugi zaś zmierza do ich rozróżnienia. Dzięki temu umysł ludzki wyposażony jest $\mathrm{w}$ dwie przeciwstawne umiejętności, pozwalające 
porządkować obiekty w kategorie i jednocześnie traktować je jednostkowo" (Stewart, 2000: 530). Nie przyjmuje kodu kulturowego jako lustrzanego, mimetycznego odbicia, ale postrzega określone wspólnoty kulturowe jako środowisko szeroko rozpowszechnionych ofert i wolnych wyborów. Analizuje zjawisko wielokulturowości jako nieustanną przestrzeń "mikrowariacji” na pewne tematy, jako sui generis partyturę dla wygrywania indywidualnej melodii. Cechuje go wyczulenie na „kreatywność kulturową” (Lubaś, 2014). Jednym z głównych czynników skuteczności terapii wielokulturowej jest wystrzeganie się myślenia etykietującego i spolaryzowanego - interpretowania świata i człowieka w kategoriach totalistycznych, standaryzujących” według schematu „wszystko albo nic”, "to albo tamto". Na zakończenie, na prawach swoistego resume, warto przytoczyć dłuższy fragment autorstwa Geralda Coreya, który stanowić może swoiste memento dla praktyki terapeutycznej podejmowanej w kontekście wielokulturowości:

W wielokulturowym społeczeństwie terapia jest $\mathrm{z}$ natury bardzo różnorodna, nietrudno więc stwierdzić, że idealnych metod terapeutycznych nie ma. Przeciwnie, różne teorie mają swoje odrębne cechy, które wydają się atrakcyjne. (...) Skuteczna praktyka wielokulturowa wymaga otwartości ze strony terapeuty, elastyczności i chęci modyfikacji strategii w ten sposób, by pasowały one do potrzeb i do sytuacji indywidualnego klienta. Terapeuta, który naprawdę szanuje swojego klienta, będzie świadom wahań i nie będzie dążył do niewłaściwego zinterpretowania jego zachowań. Przeciwnie, będzie cierpliwie próbował wejść w świat swego klienta na tyle, na ile będzie potrafił. (Corey, 2005: 53)

\section{Literatura}

Budakowska E. (2009). Wielokulturowość: ponowoczesnym nacjonalizmem? [W:] J. Królikowska (red.). Integralnokulturowe badania kontaktu kulturowego. Wybrane problemy społeczne i prawne. Warszawa.

Castells M. (2010). Społeczeństwo sieci. T. 1: Wiek informacji. Ekonomia, społeczeństwo i kultura. Przeł. M. Marody (i in.). Warszawa.

Cieciuch J. (2011). Między przedmiotem a metodą. Wątpliwości związane z koncepcja tożsamości narracyjnej McAdamsa. [W:] E. Dryll, A. Cierpka (red.). Psychologia narracyjna. Tożsamość, dialogowość, pogranicza. Warszawa.

Corey G. (2005). Teoria i praktyka poradnictwa i psychoterapii. Przeł. K. Mazurek. 2007. Poznań.

Galent M. (2014). Wielokulturowość z kulturą czy bez? [W:] D. Niedźwiecki (red.). Kultura, tożsamość i integracja europejska. Kraków.

Giddens A. (2001). Nowoczesność i tożsamość. „Ja” i społeczeństwo w epoce późnej nowoczesności. Przeł. A. Szulżycka. Warszawa.

Lubaś M. (2014). Następstwa kreatywności. Przyczynek do antropologii przemian kulturowych. [W:] D. Niedźwiecki (red.). Kultura, tożsamość, integracja europejska. Kraków.

Niedźwiecki D. (2010). Migracje i tożsamość. Od teorii do analizy przypadku. Kraków. 
Sikora K. (2008). Tożsamość jako przedmiot badań psychologii. [W:] D. Kubacka-Jasiecka, M. Kuleta (red.). W kręgu psychologicznej problematyki tożsamości. Kraków.

Skarga B. (1997). Tożsamość i różnica. Eseje metafizyczne. Kraków.

Sokolik M. (1993). Psychoanaliza i Ja. Kliniczna problematyka poczucia tożsamości. Warszawa.

Stewart J. (red.). (2000). Mosty zamiast murów. Podręcznik komunikacji interpersonalnej. Warszawa 2000.

Szahaj A. (2004). E pluribus unum? Dylematy wielokulturowości i politycznej poprawności. Kraków.

Szahaj A. (2010). Wielokulturowość: za i przeciw. (Kilka uwag). [W:] D. Pietrzyk-Reeves, M. Kułakowska (red.). Studia nad wielokulturowością. Kraków.

Taylor Ch. (2001). Źródła podmiotowości i narodziny tożsamości nowoczesnej. Oprac. nauk T. Gadacz. Wstęp A. Bielik-Robson. Warszawa.

Trzópek J. (2008). Spotkanie a tożsamość. Tożsamościotwórcze aspekty głębokich relacji międzyludzkich. [W:] D. Kubacka-Jasiecka, M. Kuleta (red.). W kręu psychologicznej problematyki tożsamości. Kraków. 
